\title{
Therapeutic characteristics of Galician mineral and thermal waters (NW-Spain) ascribed to their local/regional geological setting
}

\author{
Ricardo Juncosa Rivera ${ }^{1}$, Rosa Meijide Failde ${ }^{1}$, Jorge Delgado Martin ${ }^{1}$ \\ ${ }^{1}$ School of Civil Engineering, University of A Coruña, Campus de Elviña s/n., 15192 A Coruña, Spain
}

\begin{abstract}
Galicia is located in the NW corner of the Iberian Peninsula (Spain). From a geological point of view, the territory belongs to the Hercynian chain and, more specifically, to a large outcrop dominated by igneous and metamorphic rocks called the Hesperian Massif or Iberian Massif. In some sectors the Hesperian Massif is partially covered by more recent sedimentary deposits. The geology of Galicia is very complex due to the age of the rocks that make up its substrate and their diversity. Thus, the hydrogeological behaviour of the underground medium (hydrodynamic and hydrogeochemical characteristics) will determine the therapeutic properties of the water emanating from the surface. In Galicia, aquifers are generally shallow with low mineralization, except for those whose waters come from deep fractured mediums. The chemical characteristics of the water are directly related to the geological matrix. The groundwater flows through the geological medium and is mineralogically enriched by heterogeneous chemical reactions. Galicia turns out to be an area rich in the potential exploitation, applications and use of different water resources. These resources are thermal, mineral-natural and mineral-medicinal waters. In this work, we have developed a study that relates the geology, hydrogeological and hydrogeochemical characteristics of the Galician substrate and their potential therapeutic indications. To achieve that, we have chosen to study the exploited waters with higher flow rates, including the natural mineral waters for human use.
\end{abstract}

\section{Keywords}

Water quality; Minerals waters; Thermal waters; Medicinal waters 


\section{Introduction}

A very limited number of comprehensive studies have analysed the hydrochemistry, medical hydrology and hydrogeology in Galicia. The only studies available are focused on local areas. Regional and local studies of certain characteristics have been conducted (Juncosa et al. 2012, 2015; Delgado et al. 2007, 2011, 2013), including hydrogeochemical studies developed in specific basins. There are similar studies in NW Portugal (Carvalho 1996; Marques et al. 2012). Hernández et al. (2012), Corral et al. (2012), and Martínez-Pledel et al. (2012) can be cited, among others, as hydrogeological studies. Other studies are focused to geothermal resources (Craig 1963; Giggenbach 1992; Marques et al. 2010; Chamorro et al. 2014), although the state of knowledge of the geothermal potential of Galicia remains essentially unexplored. In terms of medical hydrology, there is extensive literature about water uses (for instance Comstock 1979; Harper 2008; Luft et al. 1990; Matz et al. 2003; Meyniel 1975; Morris et al. 2008; Valitutti et al. 1990). However, a comprehensive and global study of the hydrogeochemistry, hydrogeological and medical hydrology has not been developed for all of Galicia.

For this reason, the purpose of this study is to analyse the therapeutic characteristics of the Galician groundwater taking into account the relationship between the geology, hydrogeology and hydrochemistry of its substrate.

\section{Geological background}

Galicia is located in the NW corner of the Iberian Peninsula (Spain). Geologically, the territory belongs to the Hercynian chain. The geology of Galicia is very complex on a smaller scale, due to the ages of the rocks that make up its substrate and the diversity of the materials. Thus, it is possible to find rocks ranging from the Precambrian to the present in Galicia. Additionally, from the tectonic point of view, some of these rocks have been subjected to stresses associated with different orogenies: the Caledonian, Hercynian and Alpine. Of these orogenies, the Hercynian has left the most significant mark (e.g., Gibbons and Moreno 2002; Vera 2004; Ribeiro et al. 2007; Martínez Catalán et al. 2008).

The main outcrop lithologies in Galicia can be summarized by the following categories (Juncosa et al. 2012):

1. Metasedimentary rocks Limestones and dolomites (transformed into marbles), quartzite, shale, schist (with muscovite, biotite, and chlorite) and paragneisses. These rocks were originally sedimentary rocks that were affected by metamorphic processes related to the orogenic periods.

a. Limestones and dolomites These are located in the eastern part of Galicia, following bands from Mondoñedo (North) to Valdeorras (South).

b. Quartzites These are located in the central-eastern part of Galicia.

c. Shales These are very well developed in many areas of Galicia; but are mainly in the eastern area.

d. Schists These are also very well developed in Galicia; but are mainly in the central-western area.

e. Paragneisses The most prominent location of these rocks is the Ollo de Sapo formation, which emerges in antiformal structures from O Barqueiro to Zamora.

2. Granitic rocks These rocks are found in Galicia, especially in the central and eastern areas.

3. Basic and ultrabasic rocks (amphibolites, gabbro, diorite, peridotite, serpentinites, dunite, granulites and eclogites): These rocks are located in Cabo Ortegal, Bergantiños, Santiago, Lalin and Sobrado-Melide. 
4. Tertiary basins filled with detrital materials (clays, silts, conglomerates and, sometimes, lignite). The main basins are: As Pontes, Meirama, Vilalba, Guitiriz, Sarria, Monforte, Quiroga, Valdeorras, Maceda, Xinzo de Limia and Verín.

5. Quaternary deposits: alluvial sediments, glaciers, hillside deposits, beach and wind deposits (Corrubedo), etc.

Figure 1 shows a geological map of the main groups of rocks in Galicia.

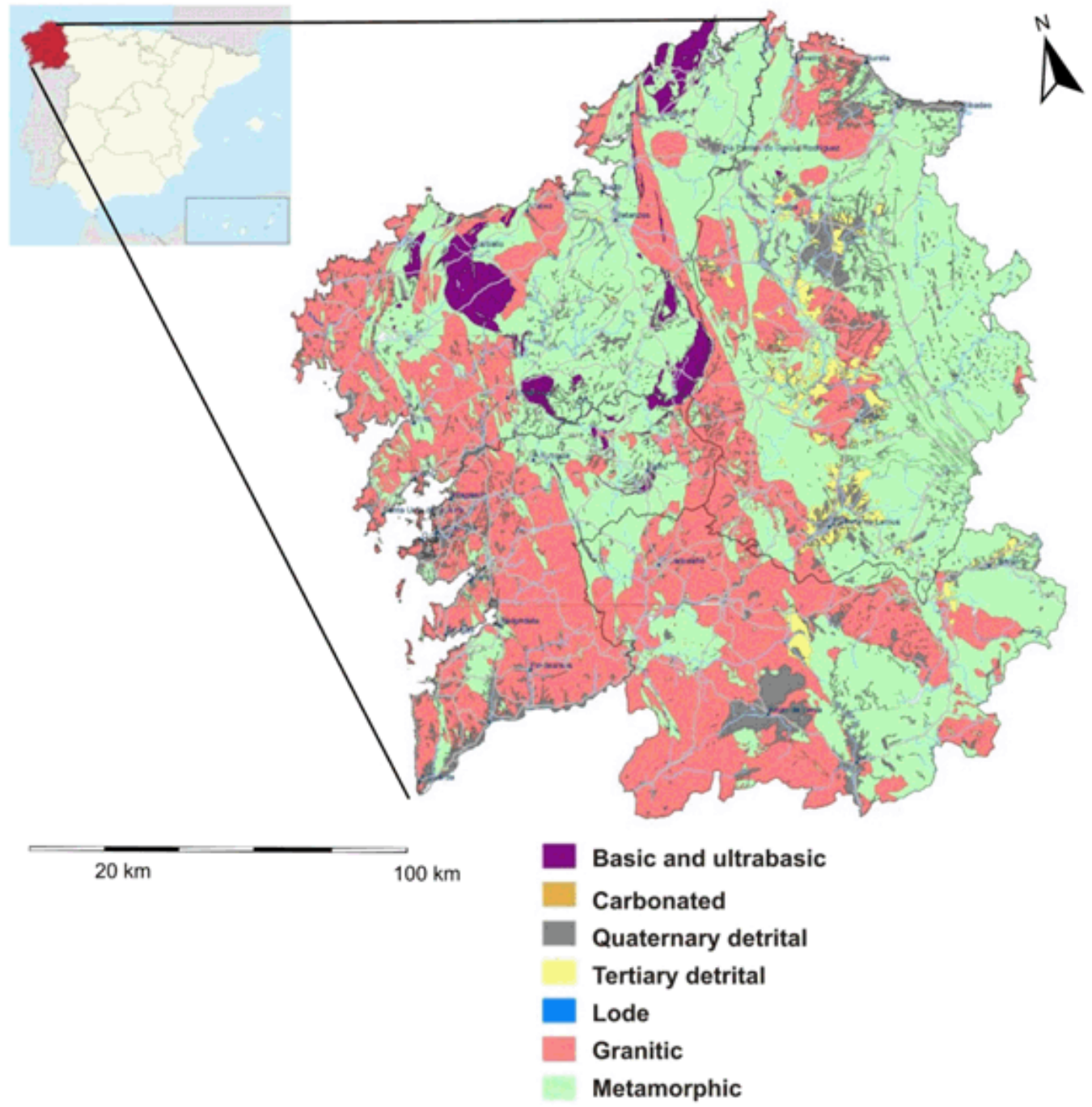

Fig. 1. Geological map of Galicia. SITGA (http://sitga.xunta.es/) 


\section{Hydrogeological characteristics}

The movement of water through the crust is the result of a number of mechanisms, such as sediment compaction, the existence of topographic gradients, variations of the water density, seismic "pumping”, diagenesis, metamorphism and magmatism (Young 1995).

Groundwater flow can develop at very different time scales according to the hydrodynamic and geological features. Similarly, groundwater can move across very different distances before emerging at surface discharge points.

Fractured igneous and metamorphic rocks (crystalline rocks) are the most abundant rocks in Galicia, presenting heterogeneity and anisotropy, coinciding mainly along flow zones with cracks and fractures. The permeability of the undisturbed rock matrix is very low, as it is conditioned by the morphometry of fractures, connections and filling. The potential to transmit and store water is very small. Therefore, the dominant hydrogeological model in Galicia depends on phreatic aquifers.

The hydrodynamic characteristics of the main Galician outcrops can be summarized as follows:

1. Carbonate formations (limestone and dolomite) and quartzite formations The secondary porosity of these formations is important (dissolution porosity in carbonates and fracture porosity). These are the formations that have the highest permeabilities in Galicia and are commonly karstified. The water flows quickly and along "channels" (Vegadeo Formation, the old mine of $\mathrm{Pb}-\mathrm{Zn}$ in Pedrafita do Cebreiro and the carbonated formation associated with Candana Group in Riotorto, Tricastela and Sarria).

2. Igneous and metamorphic lithologies Their porosity is associated with intense development of fractures. In the case of metamorphic rocks, the existence of one or more foliation families can occur. The weathering of these rocks leads to the development of superficial alterations (regolith) of variable thicknesses. The regolith can have a thickness greater than $10 \mathrm{~m}$, and its hydrodynamic behaviour is very different from the rest of the rock mass, resembling sands and gravels. The recharge occurs through massive discontinuities, so the response of the water table is usually very quick. These discontinuities can be filled by minerals (frequently clays) that limit access to water. The geometry and distribution of these aquifers are much more difficult to assess. Overall, the average permeability of these materials is low, but it can be high near the surface, where there is more intense fracturing and the discontinuities are more open.

3. Tertiary basins These basins are relatively large and discontinuous. Specially, they are sedimentation basins that currently take up the depressions in the relief (As Pontes de García Rodríguez, Meirama, Maceda, Quiroga, Monforte de Lemos, Sarria, Junceda, Visantoña, Guitiriz, Pastoriza and Vilalba). These depressions are filled with sand, clay, gravels and, sometimes, lignite layers. Hydrogeologically, the aquifers are small, but they are of interest from the point of view of the local operations. The average permeability of these units is rather low due to the existence of a high proportion of clay and silt. Its porosity is mainly an intergranular type.

4. Quaternary sediments They are continental deposits which are related to the current rivers (alluvium) and the partial erosion of Tertiary materials and continuous denudation of mountain boundary (colluviums) at certain points, and, even, sediments of glacial environment (Rey et al. 2004, Vidal Romaní and Yepes 2001).

The permeability map of Galicia can be seen in Fig. 2. This map is related to the geological map. 


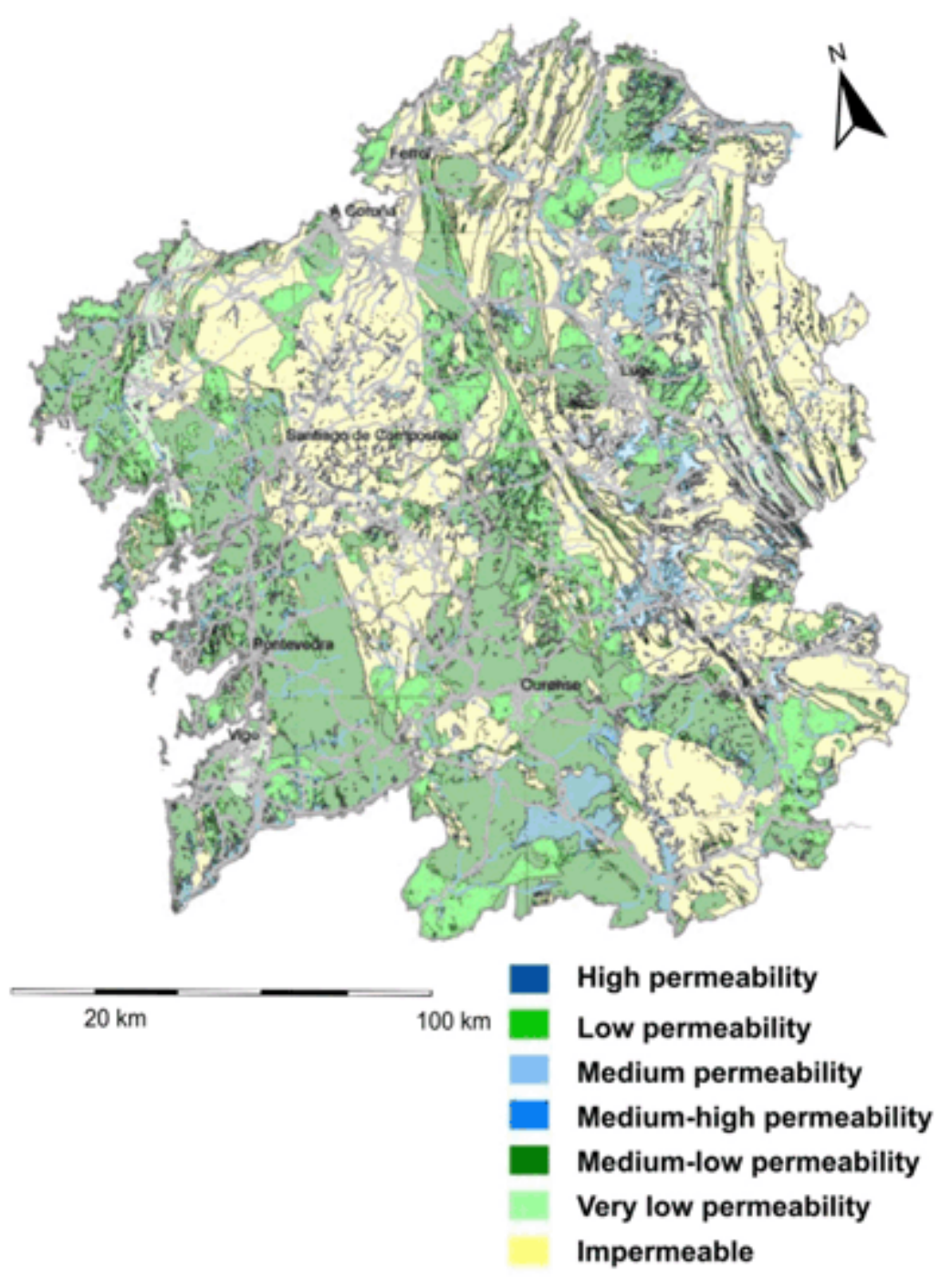

Fig. 2. Hydrogeological map of Galicia. SITGA (http://sitga.xunta.es/)

\section{Chemical and thermal characteristics of groundwater}

The chemical composition of natural waters is influenced by many factors, including aerosols and atmospheric gases, surface erosion and the weathering of rocks and sols (with biological component), the dissolution and precipitation of minerals far from the surface and human activity Stumm and Morgan (1995). The study of the processes that occur in the aqueous phase is usually performed by applying chemical thermodynamics principles. Some of these processes occur very near chemical equilibrium, although it is also necessary to consider the mechanism and reaction rates of chemical kinetics (Hounslow 1995). 
Water solutes are also part of the geochemical cycle (Hem 1991). This cycle starts with the weathering of rocks, which is the process that breaks down rocks and many of the minerals that they are made from. In this process, according to different chemical reactions, some constituents with solid phases pass through the water as solutes Henley et al. (1984). On the other hand, the decomposition of organic matter in soils releases acids that dissolve minerals. This process is called the biogeochemical cycle.

Weathering is more intense when the climate is warmer and wetter, but it is equally effective in latitudes with moderate climates, which includes Galicia. However, not all the minerals are weathered at the same speed, so the chemical fraction transferred into the water is restricted. This weathering process can be expressed by the Goldlich series (Fig. 3). As such, the concepts of flow scale and residence time are fundamental to understanding the evolution of groundwater chemistry.

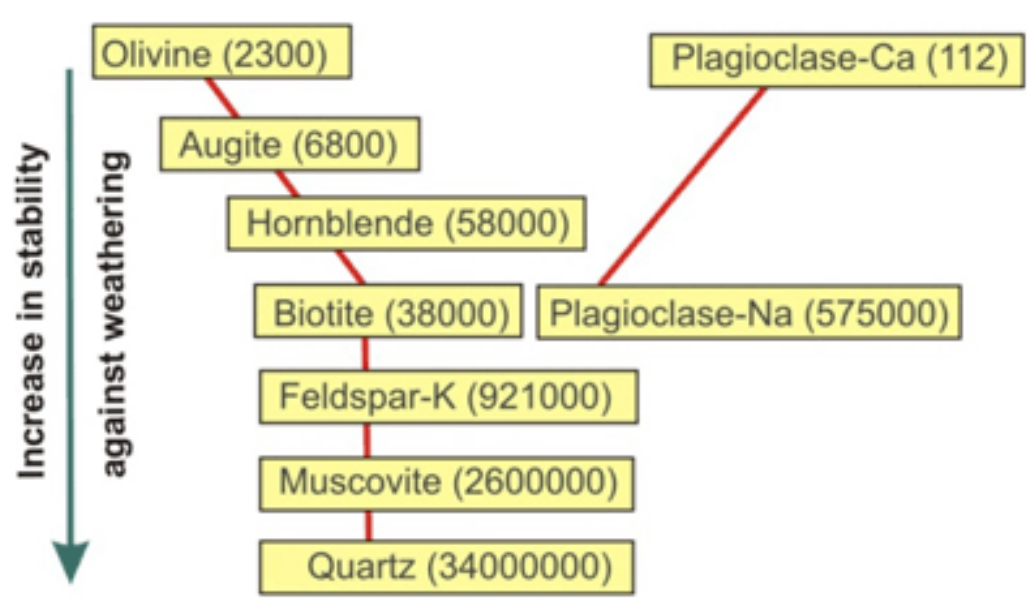

Fig. 3 Goldich series of weathering. The numbers correspond to the years required to dissolve a volume of $1 \mathrm{~mm} 3$, at pH 5 and $35^{\circ} \mathrm{C}$ (adapted from Langmuir (1996))

\section{Chemical quality}

Groundwater composition is quite variable. However, the number of major components in the water is very limited and variability (in terms of the concentration ranges) is not as important as we might have expected it to be for many of the existing lithologies and interaction processes (organic and inorganic). Thus, according to Davis and De Wiest (1966), seven elements are normally found in water at concentrations greater than $1 \mathrm{mg} / \mathrm{L}\left(\mathrm{Ca}, \mathrm{Mg}, \mathrm{Na}, \mathrm{HCO}_{3}, \mathrm{Cl}, \mathrm{SO}_{4}\right.$ and $\mathrm{SiO} 2)$, although there are 22 elements that make up $99.8 \%$ of the upper lithosphere, oceans and atmosphere. These 7 elements make up 95\% of the chemical components of groundwater. In addition, there are eight minor components often found in groundwater, at lower concentrations (0.01-10 mg/L) $\left(\mathrm{K}, \mathrm{Fe}, \mathrm{Mn}, \mathrm{Sr}, \mathrm{B}, \mathrm{F}, \mathrm{CO} 3\right.$ and $\left.\mathrm{NO}_{3}\right)$. The rest of chemical elements are typically present as trace constituents $(0.01 \mathrm{mg} / \mathrm{L})$. 
The movement of water through the unsaturated zone determines the concentrations of the major constituents and how they tend to increase. Thus, Chebotarev (1955), in a work in which he took into consideration more than 10,000 Australian groundwater analyses, concluded that these concentrations tend to chemically evolve towards the composition of seawater. He observed that this evolution is usually accompanied by regional changes in the dominant anion according to the pattern indicated by Fig. 4. Figures 5 and 6 also illustrate this observation.

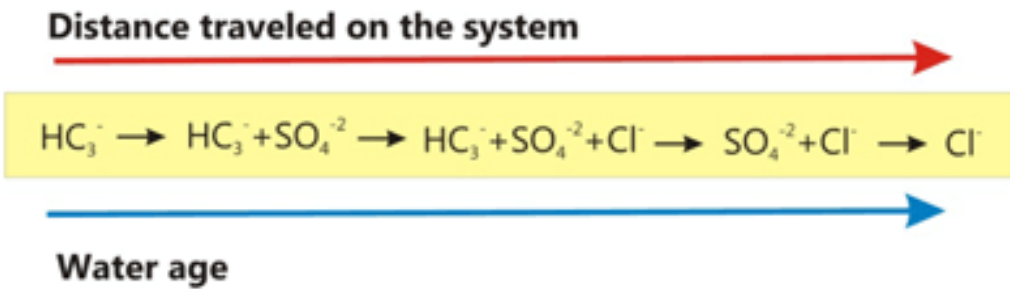

Fig. 4. Hydrochemical evolution sequence of natural groundwater (Chebotarev 1955)

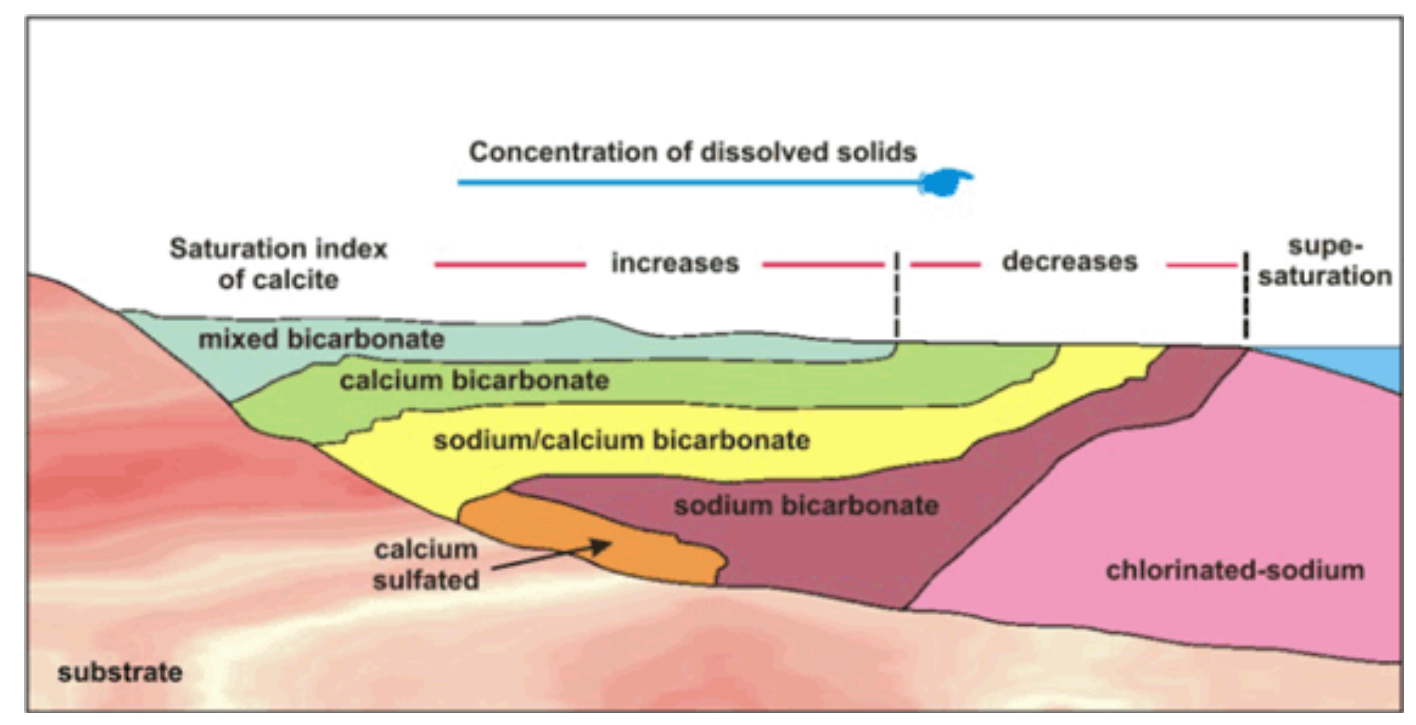

Fig. 5. Evolution of the geochemical characteristics of groundwater in the context of a coastal plain (Winter et al. 1998) 


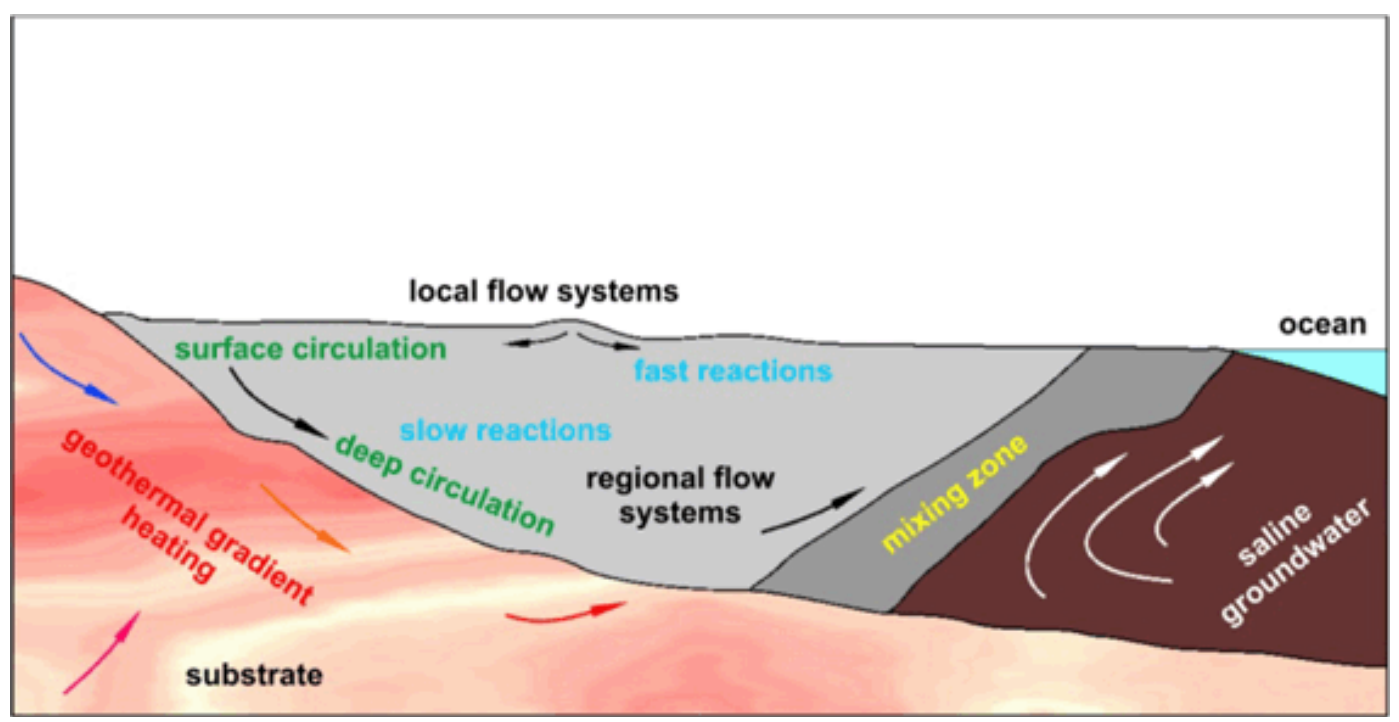

Fig. 6. Hydrogeothermal processes capable of modifying the chemical characteristics of groundwater (Winter et al. 1998)

Therefore, the hydrochemistry is associated with lithology and it is possible to establish the following groups of waters (Fig. 7):

1. Crystalline silicate rocks with coarse and medium grains This group of rocks includes igneous and metamorphic lithologies. The waters tend to be bicarbonate-sodium/potassium although springs close to the coast can have an important chlorinated component (thermal spring of A Toxa, Caldas de Reis, etc.). On the other hand, many igneous and metamorphic rocks contain potentially important amounts of sulphides, especially pyrite $\left(\mathrm{FeS}_{2}\right)$. The rise of deep water to the surface can occur such that the dissolved sulphur species do not oxidize to sulphates, leading to the formation of sulphurous springs or sources of waters (Guitiriz Spa, Baños da Brea, Termas de Cuntis, Baños Viejos de Carballo, etc.).

2. Schistose silicate (shale and phyllite) and carbonaceous rocks with low solubility These rocks have a very small primary permeability but, during their deformation, often develop a good secondary porosity (fracture porosity). They are composed of aluminium silicates, mica, quartz and iron oxides (ferruginous waters; for instance, O Incio Spa). These minerals have relatively low solubilities. Therefore, their weathering usually provides few solutes. Some of these rocks (for instance, ampelitic shales) may contain significant amounts of pyrite or other sulphide minerals capable of releasing sulphur species into the water (sulphurous waters) or, after oxidation, may provide appreciable amounts of sulphate.

3. Carbonate rocks (limestones and dolomites) These rocks provide calcium or magnesium bicarbonate waters (Vegadeo Formation, some units of Candana group).

4. Terrigenous sediments (clays, silts, sands, etc.) These sediments are poorly mineralized and are composed of sodium/ calcium bicarbonate. Most of these lithologies have a detrital origin.

5. Thermal springs and balnearies Michard and Beucaire (1993) have carried out a study of waters of different compositions and temperatures in Galicia.

6. Rainfall, river and seawater The waters of the rivers and rain in Galicia have very diluted compositions, and are slightly acidic. 
On the other hand, waters from the same type of geological massif can have very different hydrochemical characteristics. Thus, the waters with deeper circulation paths (longer residence period) have higher mineralizations than the shallow circulation waters. Additionally, at mixture of the two types of paths can occur at points of surface discharge, so it is more common to talk about families of waters with similar hydrochemical characteristics than pure waters. Mineralogy plays an important role in the chemistry of many of the components of groundwater (Chebotarev 1955; Giggenbach 1988; Coudrain-Ribstein et al. 1998).

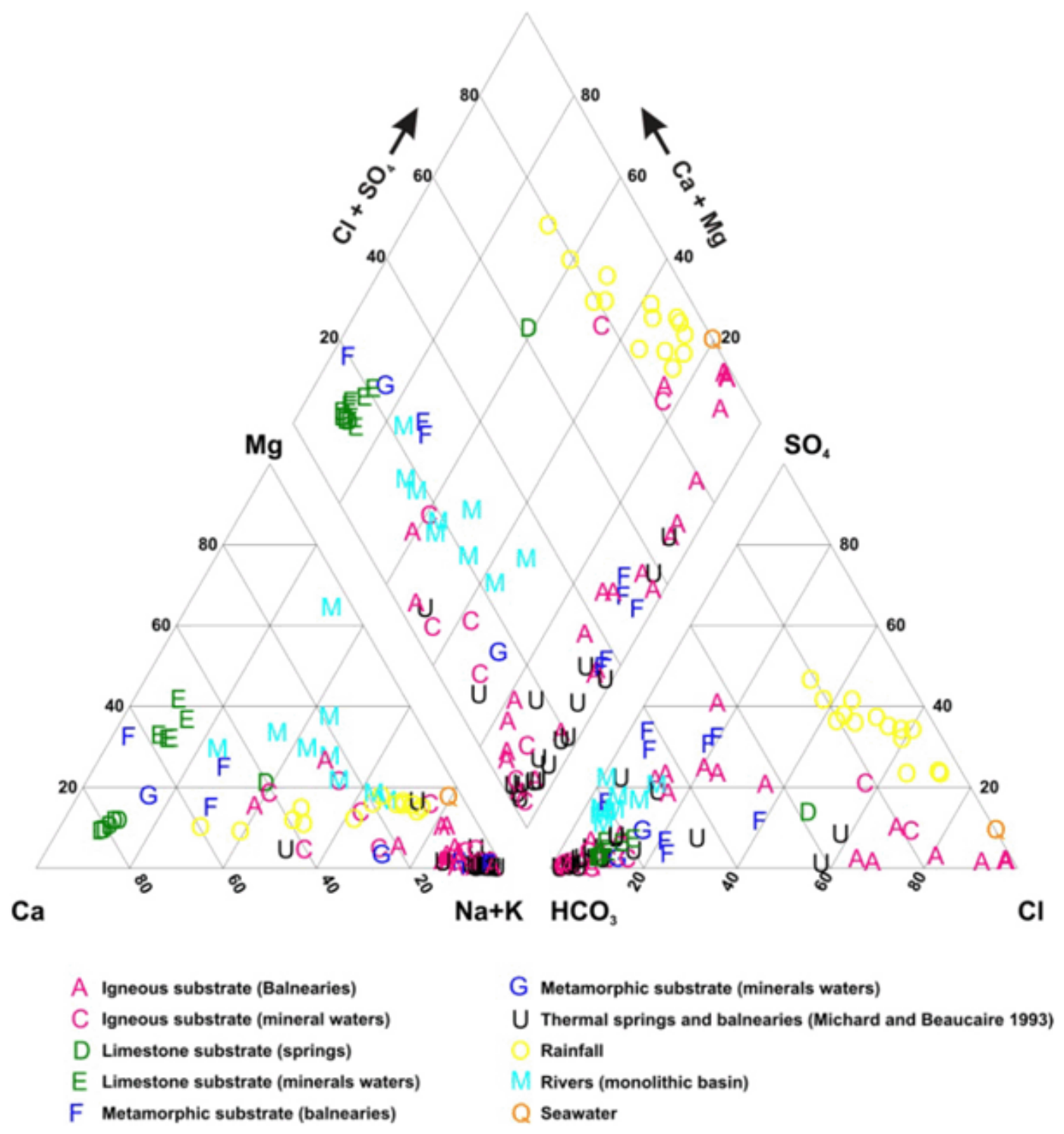

Fig. 7. Piper-Hill diagram. Data concerning the chemical compositions of the groundwaters, thermal waters, mineral waters, rivers and rainfall associated with different lithologies of Galicia 


\section{Hydrothermal quality}

Galicia is a land rich in thermal springs. Many of them have been known since ancient times and, at present, are a source of wealth. An important network of spas has developed in recent years (Fig. 8).

With regard to thermal water quality, Galicia is a region in Spain where there is a "thermal anomaly": There are zones in the South and on the border with Portugal where there are springs with the highest temperatures.

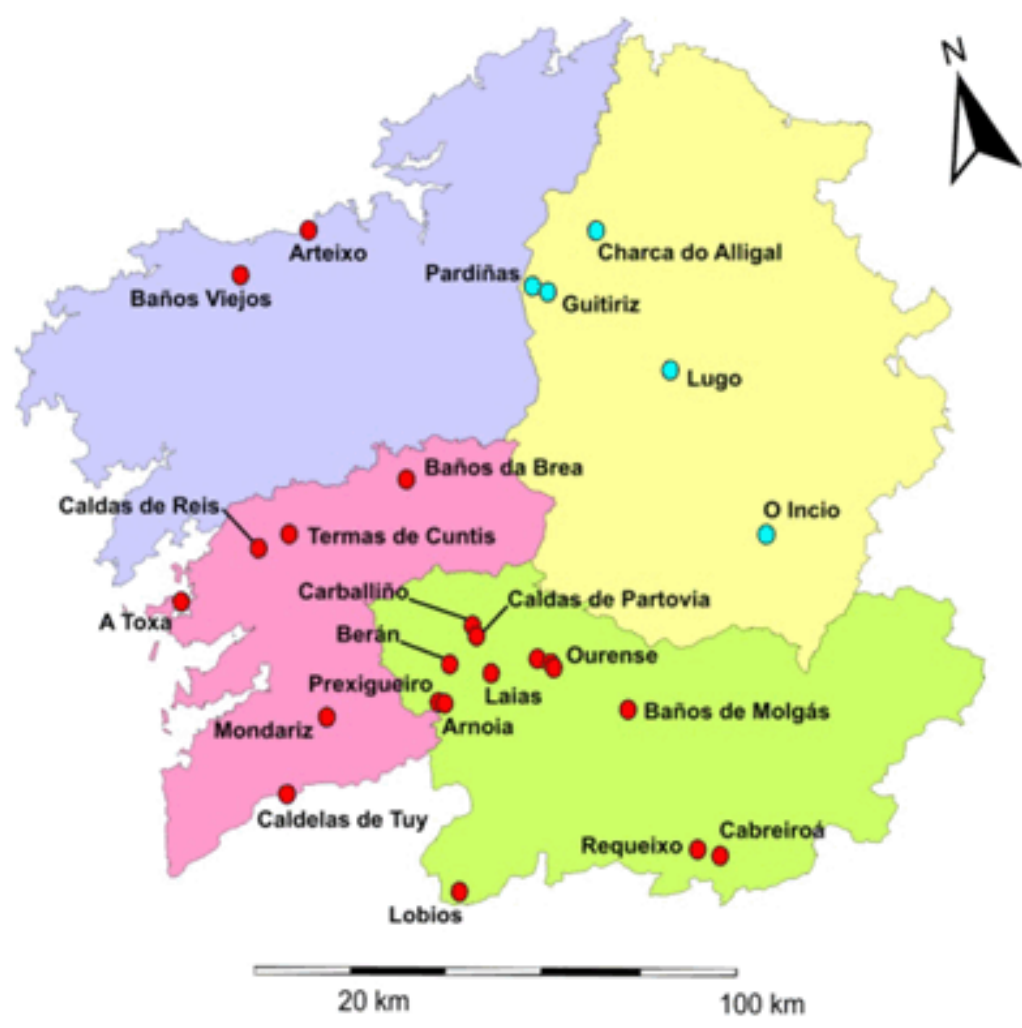

Fig. 8. Main spas and thermal springs in Galicia. Red located in an igneous substrate. Blue located in a metamorphic substrate

Michard and Beaucaire (1993) developed a study of 21 thermal springs with granitic lithologies in Galicia. Their study ignores important thermal manifestations (the cases of A Toxa, Baños Viejos de Carballo, Arteixo, etc.) and focuses on verifying a reactive model widely that has been applied to other geological contexts (French Central Massif, Corsica, Bohemian Massif, Pyrenees, Alps, etc.). Thus, these authors suggest that the composition of the different waters they studied (from carbogaseous to alkaline) can be justified by a varying original CO2 concentration and by different degrees of water/rock interaction. Thus, according to these authors, the waters in Galicia can be classified in four categories:

Group I This group has a high $\mathrm{pH}$ (alkaline) and low concentration of magnesium. It has a composition close to equilibrium with a mineral paragenesis characterized by the presence of calcite, albite, potassium feldspar, laumontite, prehnite, chlorite and chalcedony. This water would 
be the type that prevails in calc-alkaline granitoids. An example of this group would be the waters of the Termas de Cuntis.

Group II This group is similar to Group I but it would be in equilibrium with mineral paragenesis made up of calcite, albite, potassium feldspar, muscovite, laumontite, chlorite and chalcedony. Examples of this group include the water sources near Ourense, O Canedo and O Tinteiro.

Group III This group is represented by the springs located in the vicinity of Ourense (for example, Baños de Molgas, Laias Spa and As Burgas de Ourense). Concentrations of sodium, potassium, magnesium and silica are related to a mineral association similar to that described in Group II. Calcium would not be controlled by the presence of laumontite (which is absent from the mineral association) and the high bicarbonate content would not be compatible with the equilibrium with calcite. Group III represents waters with a lower degree of interaction with rocks and a greater chemical imbalance due to this.

Group IV This group includes carbogaseous waters (Mondariz Spa and Cabreiroá Spa) that demonstrate a greater chemical imbalance with the host rocks (Fig. 9).

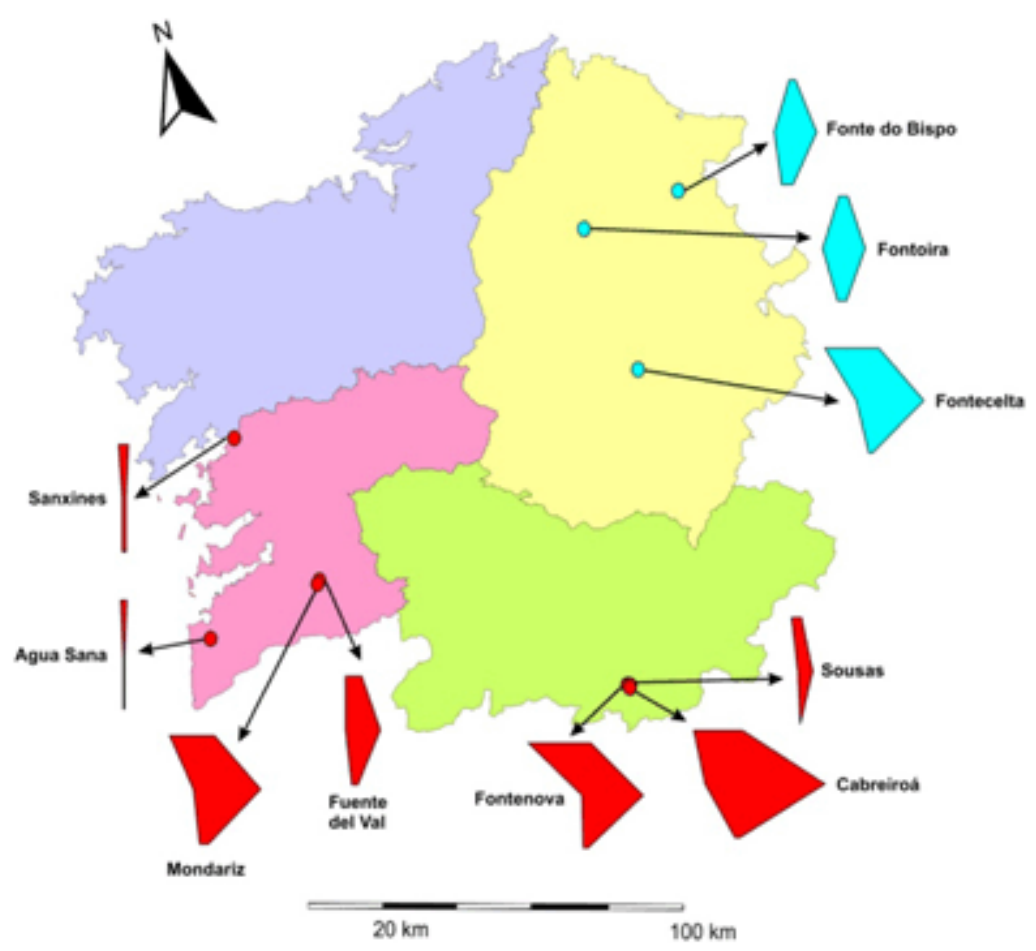

Fig. 9. Springs of mineral waters in Galicia and their stiff diagrams. Red located in an igneous substrate. Blue located in a metamorphic Substrate

The temperatures measured at the points of thermal water upwelling do not usually coincide with the temperatures at the maximum depth at which the waters are heated. This lack of similarity is due to many of processes that cause cooling. According to D'Amore (1991) the most important processes are: (1) adiabatic boiling (i.e., the physical separation of a vapor phase without heat exchange with the rock), (2) heat dissipation by thermal conduction to the rock, (3) mixing with cold surface waters, and (4) a combination of the previous processes. 
Chemical analysis of the thermal waters provides useful information for identifying these processes. Waters that rise quickly from deep aquifers with no conductive cooling often have a chemical composition that reflects the water/rock equilibrium at the aquifer temperature. However, the cooling of the waters by conduction is produced when the ascent to the surface is slow (D’Amore 1991). These slow-moving waters can even travel horizontally before surfacing. As a result, rows of springs can be found with very similar chemical compositions but with very different temperature (Mahon 1966; Fournier and Rowe 1966; Fournier and Potter 1982). Moreover, when the rising hot water is cooled via mixing with surface waters, the springs can show different chemical and thermal characteristics.

\section{Classification of groundwater in Galicia}

\section{Typology of water}

The planning and management of mineral and thermal waters in Galicia is performed by a set of management criteria. Therefore, the following water classification has been developed into a law, D1798/2010, as shown in Table 1.

\begin{tabular}{llll}
\hline Regulation of mineral waters and thermal waters & & Thermal waters \\
\hline Type & Mineral waters & Mineral-industrial waters & \\
& Mineral-medicinal waters & & \\
& For therapeutic purposes & Springs waters $\quad$ Natural waters &
\end{tabular}

Table 1. Classification of waters according to Law D1798/2010

The different categories can be defined as follows:

- Mineral-medicinal waters for therapeutic purposes The naturally or artificially occurring waters that are declared of use to the public and that are suitable for therapeutic treatments. For this, they must have certain qualities.

- $\quad$ Spring waters Those waters of underground origin that emerge spontaneously or are captured by labors made for this purposes. They are naturally pure.

- Natural waters Waters that are healthy bacteriologically, with underground origins, that emerge at one or more points of upwelling. They can be clearly distinguished from drinking water by their nature and original purity, characterized by their mineral contents, trace elements and favourable effects. They can be drunk.

- Mineral-industrial waters Waters that allow the safe use of the contained substances. The sea water used for this purpose is included.

- Thermal waters Waters whose upwelling temperature is four Celsius degrees higher than the average annual temperature of the area where they emerge, that are declared of use to the public and that are suitable for therapeutic uses in spas.

Several authors (Souto 1990; Baeza et al. 2001) have inventoried the mineral waters and thermal waters in Galicia. 


\section{Classification of water according to physical and chemical characteristics}

Of the physical characteristics of the water, temperature is the most widely used criterion for classifying mineral water. The most useful classifications, from a medical point of view, are those that consider the water temperature in relation to body temperature, since external applications of mineral-medicinal water will almost always take body temperature into account.

From a therapeutic point of view, the criteria used to classify the mineral-medicinal waters in Spain are also used in other countries. The most common classifications are those that take into account the total mineralization and the predominant anion and cation content, those that account for the presence of special components, or those that classify by physical properties, such as temperature.

In Spain, the classification proposed by Armijo and San Martín, and published by Maraver (Maraver 2002), is used for medical hydrology. For this study, the different criteria developed in the different European countries have been considered. There is the Latin approach, in which a mineral-medicinal water is water with therapeutic properties, regardless of the total amount of minerals, and the Germanic criterion, in which it is necessary to have a minimum amount of dry residue and chemical components to be considered mineral-medicinal water; meanwhile, Spain has followed a mixed approach (Table 2).

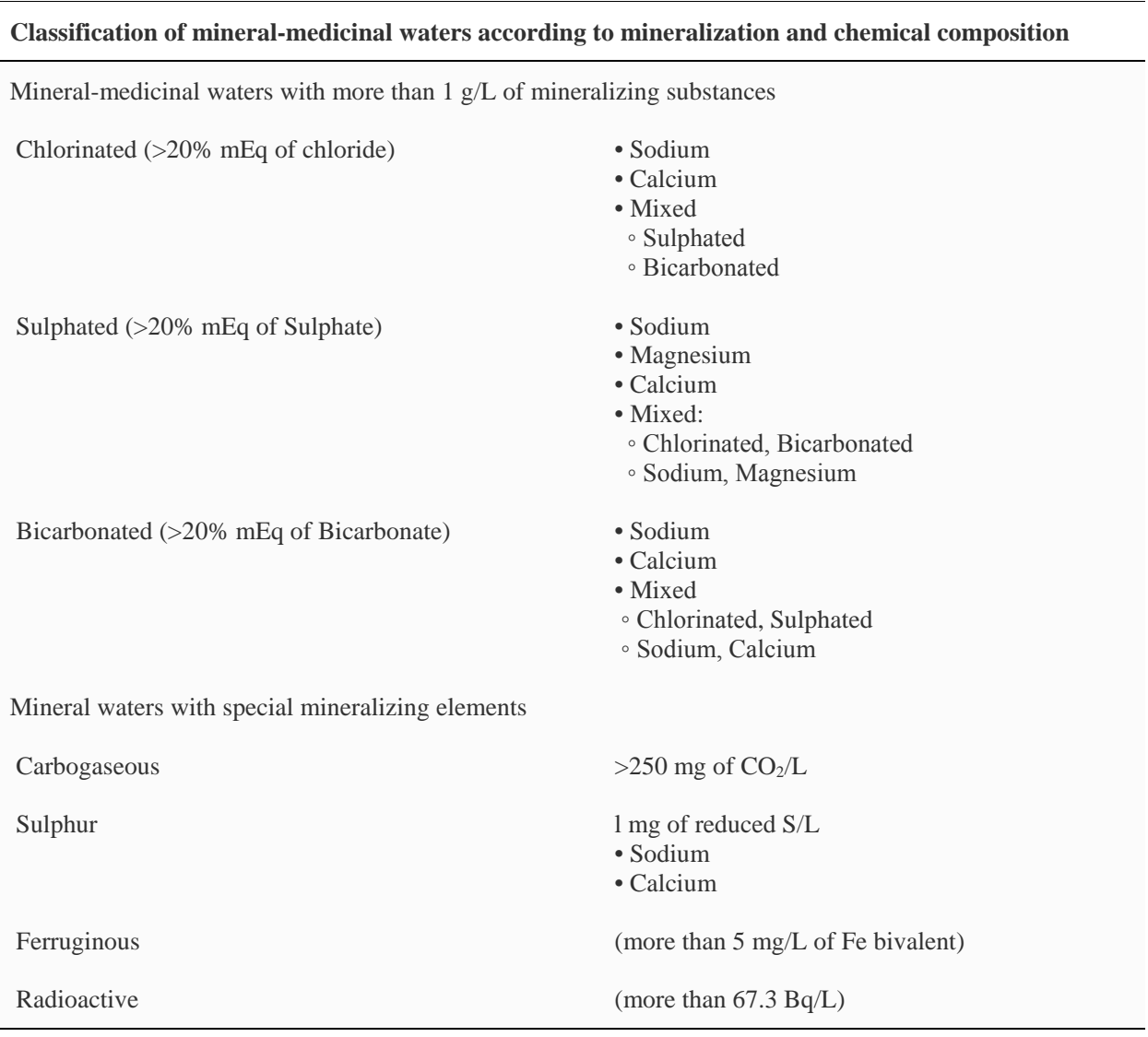

Table 2. Classification of the mineral-medicinal waters according to chemical composition (D1074/2002) 


\section{Classification of water in Galicia according to temperature}

According to the criteria described, the waters of the Galician spas and springs with mineralmedicinal contents can be categorized from a thermal point of view as shown in Table 3.

\begin{tabular}{|c|c|c|}
\hline Designation & Temperature ${ }^{\circ} \mathrm{C}$ & Spas and springs \\
\hline Cold & $<19.9$ & $\begin{array}{l}\text { Augas Santas-Pantón } \\
\text { Agua de Fonte Nova: main spring } \\
\text { Agua Cabreiroa with Gas } 2 \\
\text { Sousas: spring } 1 \\
\text { O Tremo } \\
\text { Mondariz (Gándara) } \\
\text { Guitiriz } \\
\text { Rio Pambre } \\
\text { O Incio }\end{array}$ \\
\hline $\begin{array}{l}\text { Hypothermal } \\
T<T_{\text {aa }}+4^{\circ} \mathrm{C}\end{array}$ & $20-34.9$ & $\begin{array}{l}\text { Baños de Berán } \\
\text { O Carballiño } \\
\text { Ponte Caldelas } \\
\text { Acuña } \\
\text { Charca do Allegal } \\
\text { Baños de Brea } \\
\text { Arnoia } \\
\text { Fonte do Bañiño }\end{array}$ \\
\hline $\begin{array}{l}\text { Mesothermal } \\
T=T_{\mathrm{aa}}+4^{\circ} \mathrm{C}\end{array}$ & $35-36.9$ & $\begin{array}{l}\text { Caldas de Partovia } \\
\text { Arteixo }\end{array}$ \\
\hline $\begin{array}{l}\text { Hyperthermal } \\
T>T_{\text {aa }}+4{ }^{\circ} \mathrm{C}\end{array}$ & $37-60$ & $\begin{array}{l}\text { Baños de Loureda } \\
\text { Baños Viejos de Carballo } \\
\text { Laias } \\
\text { Baños de Molgas } \\
\text { Dávila } \\
\text { Caldelas de Tui } \\
\text { Cortegada } \\
\text { Lugo } \\
\text { A Toxa }\end{array}$ \\
\hline & $>60$ & $\begin{array}{l}\text { Lobios } \\
\text { Xardin das Burgas } \\
\text { Termas de Cuntis }\end{array}$ \\
\hline
\end{tabular}

T spring temperature, $\mathrm{T}_{\text {aа }}$ average annual temperature

Table 3. Classification of waters according to upwelling temperature

\section{Classification of water in Galicia according to mineralization and chemical components}

From the point of view of overall mineralization, mineral-medicinal waters can be classified by their dry residue at $180{ }^{\circ} \mathrm{C}$. The mineral-medicinal waters with low mineralization (250-500 $\mathrm{mg} / \mathrm{L}$ ) are predominant in Galicia (36\% of the total). Medium mineralization waters (500-1000 $\mathrm{mg} / \mathrm{L})$ account for $24 \%$ of the total. High mineralization waters (>1000 mg/L) also account for $24 \%$ of the total. Finally, the waters with very low mineralization represent $16 \%$ of the total.

From a standpoint of special mineralizing elements, spas using carbogaseous waters with more than $250 \mathrm{mg} / \mathrm{L}$ free CO2 include the Mondariz Spa (Gandara) (988.9 mg/L), Agua de Cabreiroá with Gas 2 (705 mg/L) and Agua Fonte Nova - main spring (631 mg/L). 
The waters of the Galician spas are, in general, very soft waters $\left(0-100 \mathrm{mg} / \mathrm{L}\right.$ of $\left.\mathrm{CaCO}_{3}\right)$, as expected for terrain with high calcium contents. The Arteixo spa is an exception, with waters that are soft $\left(100-200 \mathrm{mg} / \mathrm{L}\right.$ of $\left.\mathrm{CaCO}_{3}\right)$, as is the A Toxa spa, which has extremely hard waters $(>400$ $\mathrm{mg} / \mathrm{L}$ of $\left.\mathrm{CaCO}_{3}\right)$.

The A Toxa spa waters are unique due to their high concentrations, moderate temperatures $\left(40-47^{\circ} \mathrm{C}\right.$ ) and their sodium-chloride contents. The waters here have a significantly lower magnesium content (also potassium and sulphate) and a higher fluorine, calcium and carbonates content than seawater. Thus, the origin of the water of A Toxa is due to seawater and intense interactions with the surrounding rocks. The reduction in the sulphate content could be caused by the precipitation processes associated with the electrochemical reductions at depth $\left(\mathrm{SO}_{4} \rightarrow \mathrm{HS}\right)$ and the increase in the carbonates due to the dissolution of calcites under the partial pressure conditions of a higher $\mathrm{CO}_{2}$ value than the partial pressure of the atmosphere, fixing magnesium and potassium (predictably by forming phyllosilicates) and leaching some amount of fluoride and calcium. (Coudrian-Ribsterin et al. 1998).

Moreover, one characteristic of the Galician waters is the presence of high silica and fluoride concentrations, which results from the geomorphology of the reliefs. The $\mathrm{pH}$ of the Galician springs is acidic in the carbogaseous bicarbonate waters (Gandara in Mondariz, Cabreiroá, Fontenova, Sousas and A Toxa) and is alkaline or highly alkaline elsewhere.

A preliminary inspection of the water from different Galician spas show that, except for the A Toxa spa (and the Arteixo spa and springs “Troncoso" and "Estrella” from Mondariz), most of the waters are relatively diluted (Figs. 10,11). This dilution could imply a relatively short residence time in the substrate. Additionally, the waters are mainly bicarbonate-sodium type (including Mondariz), with notable sodium-chloride exceptions, (A Toxa, Arteixo, and springs and sources of Caldas de Reis) and one bicarbonate-calcium type (O Incio). O Incio is not really a thermal system, but rather is a ferruginous source that takes its composition from a relatively shallow trip through shale.

Figure 12 shows a triangular diagram of the most representative anions of the typical thermal springs. This scheme, proposed by Giggenbach and Goguel (1989), was originally intended for magmatic-hydrothermal systems but it has been used in a generalized form to classify the thermal springs preliminarily. In summary, the diagram divides the waters according to their relative chloride, sulphate and bicarbonate contents.

Most of the thermal springs are projected in the lower right section of the figure, within the domain called the "peripheral waters." According to Giggenbach $(1988,1997)$, this area is characterized by the existence of water that, having interacted with the bedrock, would not have reached chemical equilibrium with it. On the other hand, the water compositions near the vertex of chloride would be in the domain of "mature water", i.e., those who have interacted with rocks enough to have approached significant chemical equilibrium with them. Several water samples are located in the field of "mature water", particularly those belonging to the Arteixo spa, Caldas de Reis (Davila Acuña) and A Toxa (Juncosa et al. 2011).

Figure 13 shows a Giggenbach triangular diagram (Giggenbach 1988) for cations of K, Na and $\mathrm{Mg}$ in the waters of the spas and thermal springs in Galicia, as well as for some of northern Portugal, which distinguishes whether the springs are located on igneous or metamorphic substrates, if the springs has carbogaseous waters and the particular case of A Toxa. In two curves are represented in Fig. 13. 

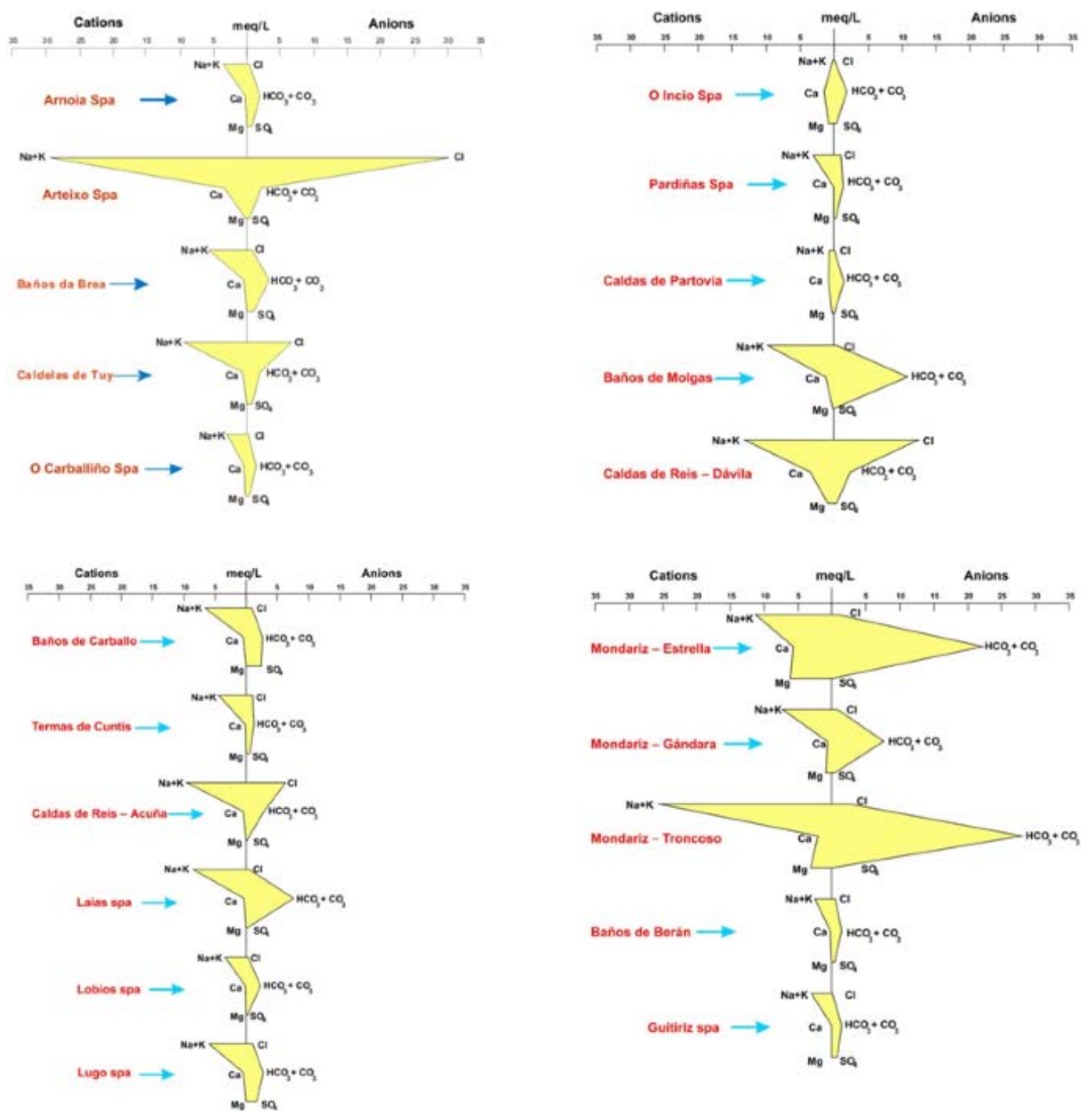

Fig. 10. Stiff diagrams of the mineral waters in Galicia 


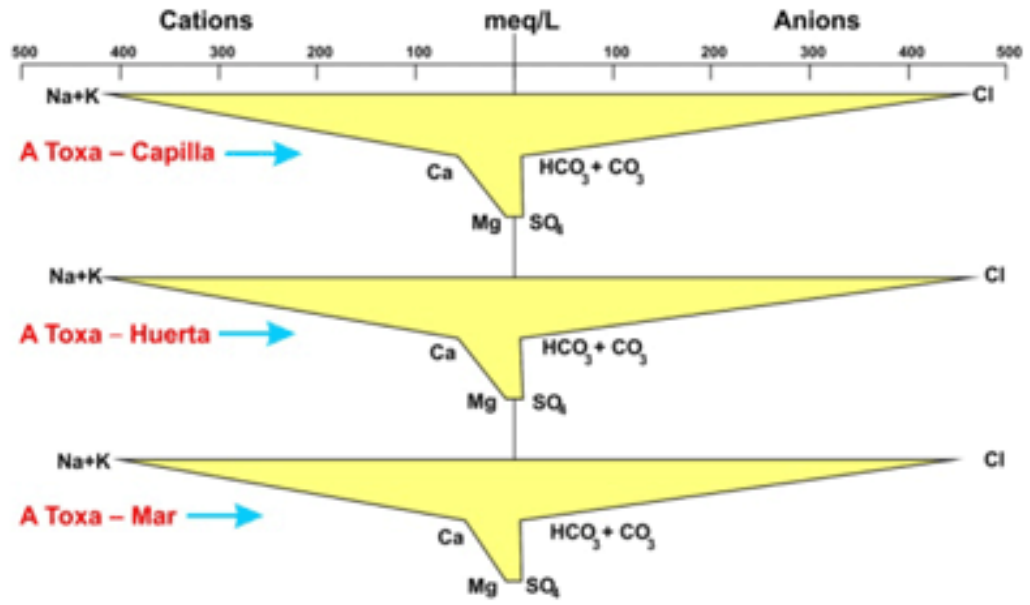

Fig. 11. Stiff diagrams of some springs from the A Toxa spa

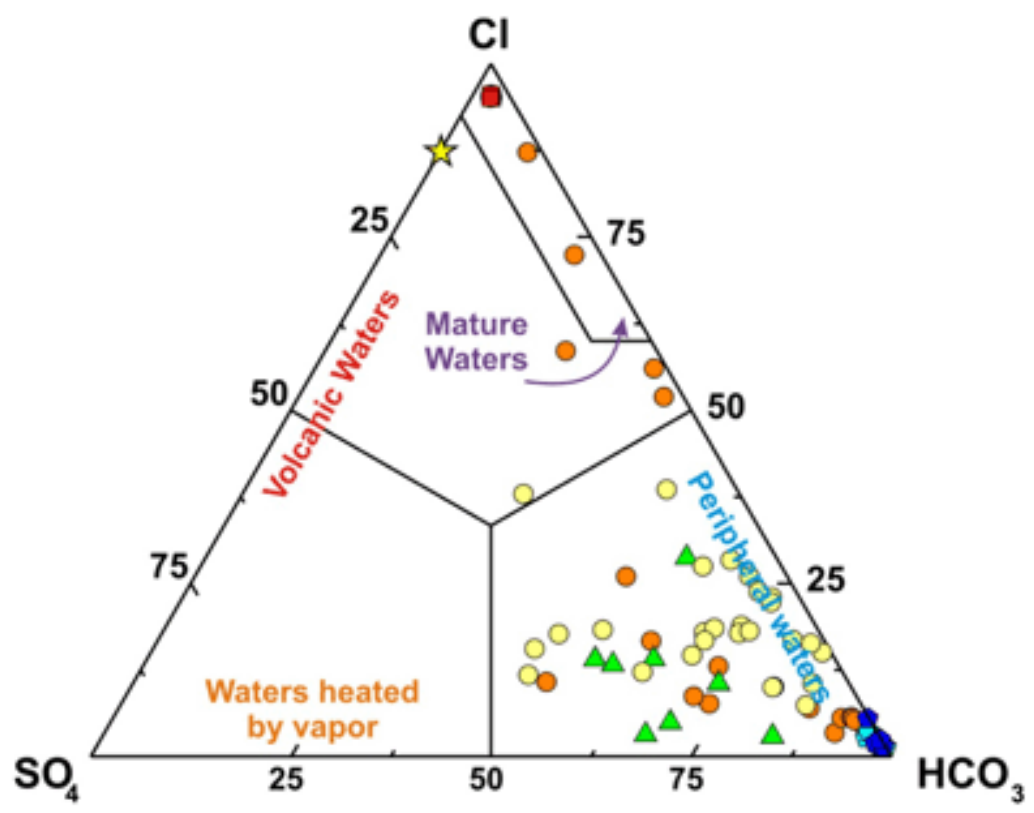

Fig. 12. Diagram of Cl-HCO3-SO4 (mg/L) of Giggenbach and Goguel (1989) of the spas and thermal springs of Galicia and northern Portugal. Igneous substrate the orange circles (Galicia) and yellow circles (northern Portugal: Vilarelho da Raia, Chaves, Pedras Salgadas, Vidago, São Lourenço, Carlão y Caldas do Moledo). Metamorphic substrate green triangles. Carbogaseous waters dark blue pentagons (Verín and Mondariz) and light blue pentagons (northern Portugal). Waters of A Toxa spa red squares. 


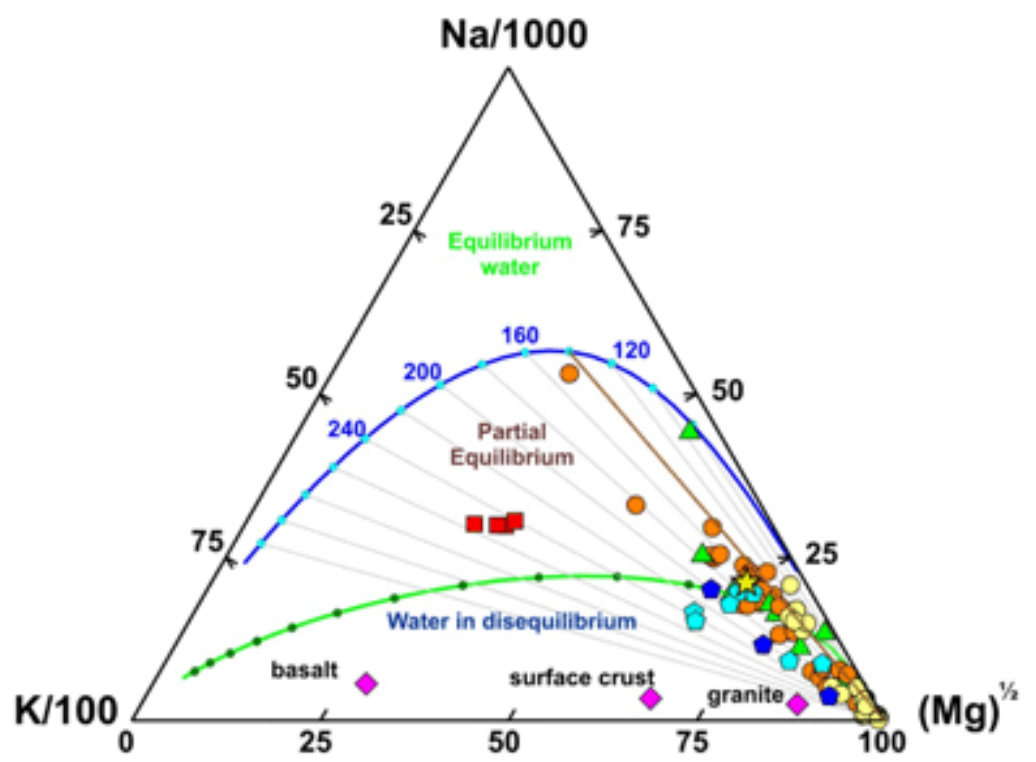

Fig. 13. Giggenbach triangular diagram (Giggenbach 1988). Spa water composition and thermal springs in Galicia are plotted. Igneous substrate brown circles (Galicia) and yellow circles (northern Portugal: Vilarelho da Raia, Chaves, Pedras Salgadas, Vidago, São Lourenço, Carlão y Caldas do Moledo); metamorphic substrate green triangles; carbogaseous waters dark blue pentagons (Verín) and light blue pentagons (northern Portugal); waters of A Toxa spa red squares. The average compositions of basalts, granites and rocks of the upper crust are also plotted.

In the triangular diagram, Giggenbach usually showed two curves that divide the area of the plot into three main domains: overall balance, partial equilibrium and disequilibrium. The equilibrium curve is calculated from the geothermometric relationships that Giggenbach suggested for $\mathrm{K} / \mathrm{Na}$ and $\mathrm{K} / \mathrm{Mg}$ ionic pairs, which represent the interactions of the natural waters with the minerals of crustal rocks. Similarly, since the equilibrium of the K/Mg system is reached faster (at lower temperature) than that of the K/Na system, Giggenbach proposed a second curve that would show the waters that have not reached total $\mathrm{K} / \mathrm{Mg}$ and $\mathrm{K} / \mathrm{Na}$ equilibrium. These waters would be in transit towards this equilibrium.

The area of water in disequilibrium (i.e., immature water) represents those waters with compositions that are the product of the dissolution of minerals present in the rocks without reaching equilibrium. According to Giggenbach (1997), high magnesium content is incompatible with high temperatures, which denotes the acquisition of this element at low temperatures (for example, via water/rock interactions at low temperature or via mixing with colder fluids) or a high degree of immaturity.

On the other hand, most of the analysed waters define a linear trend (brown line) that would suggest a partial equilibrium at a maximum temperature of approximately $140{ }^{\circ} \mathrm{C}$. That is, a significant portion of the water could come from at mixture of deeper water (with reservoir temperatures of approximately $140{ }^{\circ} \mathrm{C}$ ) with surface water. Assuming a normal geothermal gradient $(\sim 32 \mathrm{mK} / \mathrm{m})$, the depth of the thermal water reservoir would be located $3-4 \mathrm{~km}$. However, using the Iberian Massif gradient $(\sim 25 \mathrm{mK} / \mathrm{m})$ gives a depth of $4-5 \mathrm{~km}$. 
Furthermore, A Toxa waters are outside of the range of the other waters, within the scope of partial equilibrium and are apparently associated with a reservoir of a higher temperature. It is worth noting that the magnesium content of the waters of A Toxa is much lower than in other waters, with concentrations close to the equilibrium values for basaltic rocks. In this case, it is difficult to establish a link between these waters and the deep circulation of seawater through a basaltic oceanic crust.

The K/Ca and K/Mg ratios of the thermal springs generally reach equilibrium faster than those associated with other geothermometers (for example K/Na) (Giggenbach 1988). It is an accepted fact that the presence of calcium in water is associated with the presence of calcite in rocks. The solubility of calcite depends on temperature, $\mathrm{pH}$ and the partial pressure of $\mathrm{CO}_{2}$ (Fig. 14). However, these ionic ratios are also likely to reflect situations of rebalancing. In this case, the temperatures would reflect lower thermal conditions than the reservoir temperatures where the thermal waters originated. Additionally, mixing with surface water (which is richer in magnesium and bicarbonate) can distort their meaning.

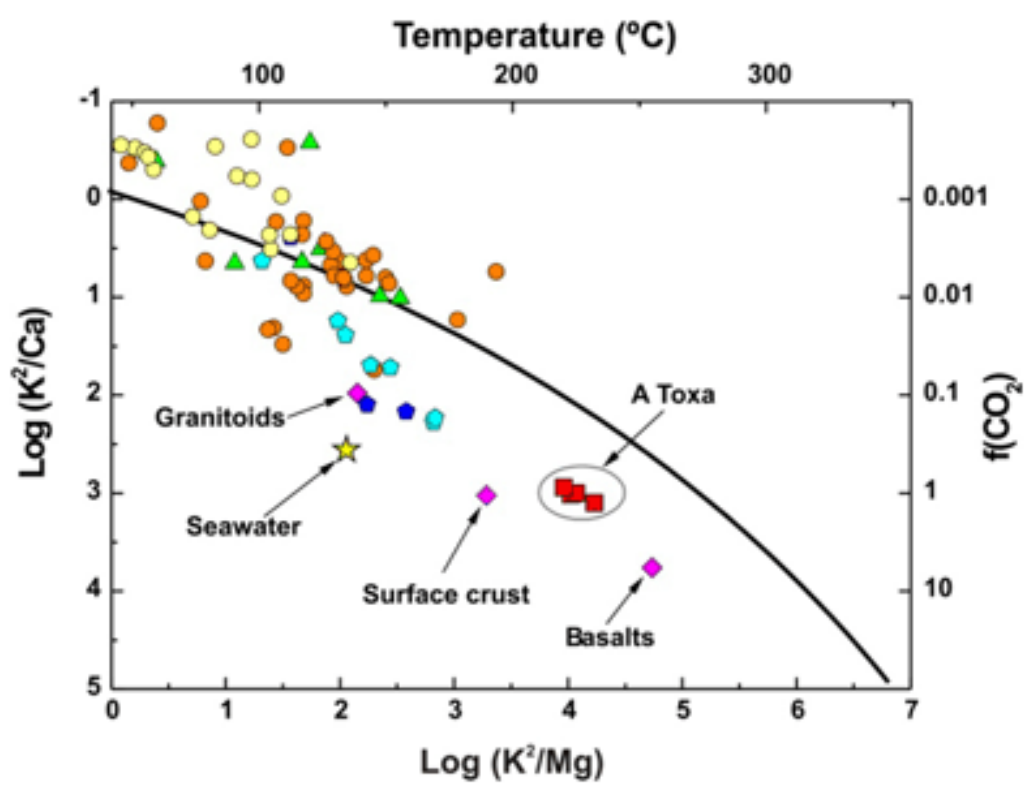

Fig. 14. Spas and thermal springs of Galicia and northern Portugal. (V). The log ( $\left.\mathrm{K}^{2} / \mathrm{Mg}\right) \mathrm{vs}$. $\log \left(\mathrm{K}^{2} / \mathrm{Ca}\right)$ (or temperature vs. fugacity of $\mathrm{CO}_{2}$ ) diagram corresponding to the igneous substrate (Galicia, orange circles; northern Portugal: Vilarelho da Raia, Chaves, Pedras Salgadas, Vidago, São Lourenço, Carlão y Caldas do Moledo, yellow circles) and the metamorphic substrate (green triangles). A Toxa waters red square. Carbogaseous waters pentagons (Verín, in dark blue, and northern Portugal, -Chaves, Vilarelho da Raia, Vidago, Pedras Salgadas- in light blue).

Figure 14 shows the $\mathrm{K} / \mathrm{Ca}$ and $\mathrm{K} / \mathrm{Mg}$ relationships of the waters analysed in this paper. A curve representing the linkage of bicarbonate to granitic rocks is also shown. The precipitation of calcite is promoted by higher temperatures. This reaction can be expressed as follows:

$$
\text { Silicate }-\mathrm{Ca}-\mathrm{Al}+\mathrm{CO}_{2}+\mathrm{H}_{2} \mathrm{O} \rightarrow \mathrm{CaCO}_{3}+\text { clays }
$$

It is interesting that most of the water fit the above theoretical trend reasonably well. In fact, there is a remarkable similarity between these data and the data provided by Coudrain-Ribstein et al. (1998) (who proposed analogous reactions in relation to the natural $\mathrm{CO}_{2}$ content in groundwater). This does not occur in the A Toxa waters and in carbogaseous waters. 
The carbogaseous waters represented in Fig. 14 demonstrate that $\mathrm{CO}_{2}$ fugacities are higher than those described by the reaction of carbonate fixation. Many authors have suggested a deep origin (in the mantel) for the $\mathrm{CO}_{2}$ of some of the next thermal sources (Marques et al. 2000, 2001, 2003). The presence of $\mathrm{CO}_{2}$ in the upper mantle has been inferred from decarbonation reactions of $\mathrm{MgCO}_{3}$ and $\mathrm{CaCO}_{3}$. The $\mathrm{CO}_{2}$ fugacities for the decarbonation reactions indicate that $\mathrm{CO} 2$ is more compressible at high pressures than previously predicted (Haselton et al. 1978). A Toxa waters are significantly different from the rest of the waters in this study. In Tables 4, 5, 6 and 7 the main chemical compositions of Galician waters are shown.

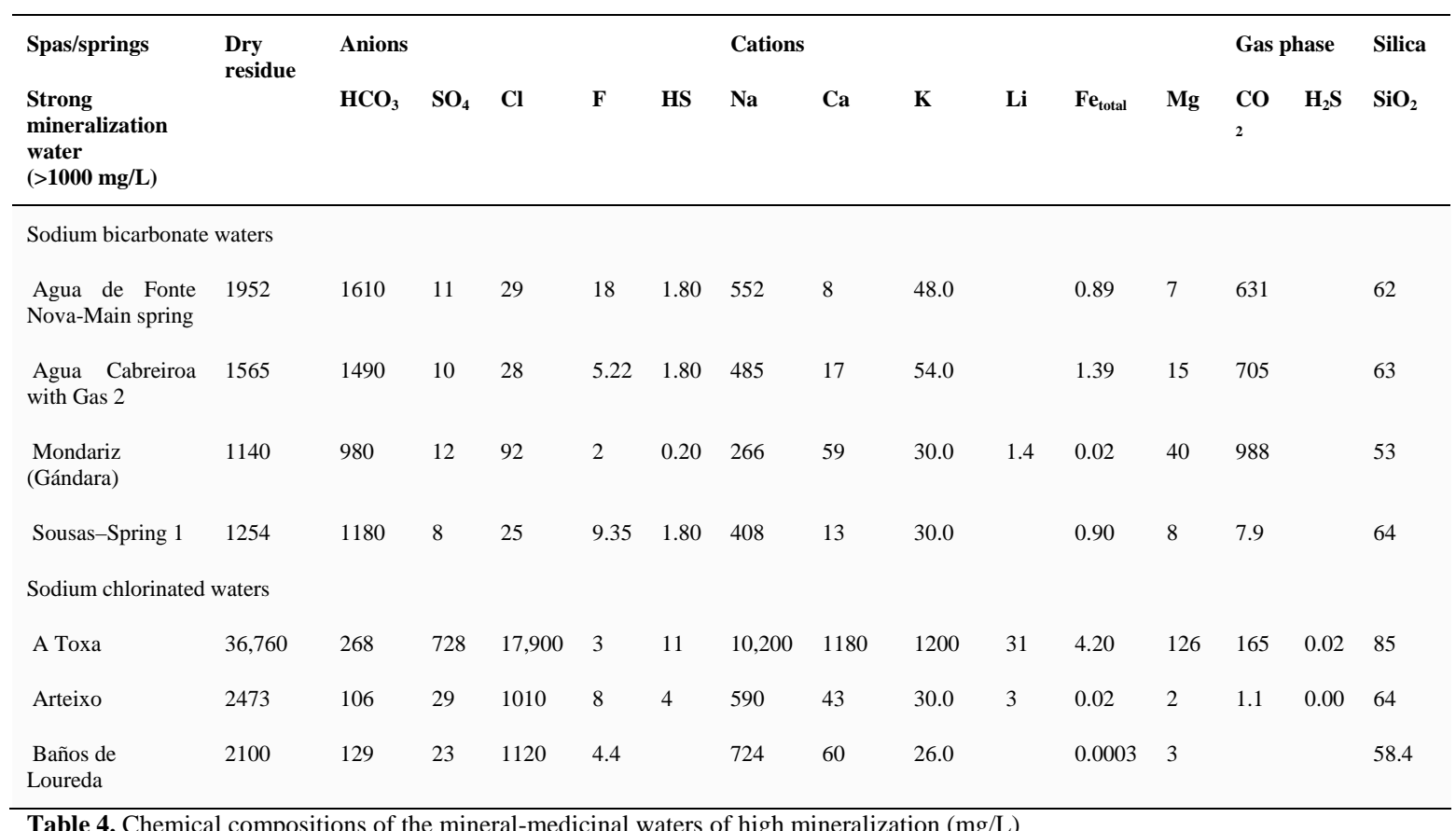

Table 4. Chemical compositions of the mineral-medicinal waters of high mineralization (mg/L)

\begin{tabular}{|c|c|c|c|c|c|c|c|c|c|c|c|c|c|c|c|}
\hline \multirow{2}{*}{$\begin{array}{l}\text { pas/springs } \\
\text { Medium mineralization } \\
(500-1000 \mathrm{mg} / \mathrm{L})\end{array}$} & \multirow{2}{*}{$\begin{array}{l}\text { Dry } \\
\text { residue }\end{array}$} & \multicolumn{5}{|l|}{ Anions } & \multicolumn{6}{|l|}{ Cations } & \multicolumn{2}{|c|}{ Gas phase } & \multirow{2}{*}{$\begin{array}{l}\text { Silica } \\
\mathrm{SiO}_{2}\end{array}$} \\
\hline & & $\mathrm{HCO}_{3}$ & $\mathrm{SO}_{4}$ & Cl & $\mathbf{F}$ & HS & $\mathrm{Na}$ & $\mathrm{Ca}$ & $\mathbf{K}$ & $\mathbf{L i}$ & $\mathbf{F e}_{\text {total }}$ & Mg & $\begin{array}{l}\text { CO } \\
2\end{array}$ & $\mathbf{H}_{2} \mathrm{~S}$ & \\
\hline \multicolumn{16}{|l|}{ Sodium bicarbonate waters } \\
\hline Baños de Molgas & 706 & 636 & 7 & 22 & 14 & 2.2 & 250 & 10 & 11 & & 0.096 & 1 & 40.7 & 9.10 & 66 \\
\hline Laias & 539 & 400 & 28 & 35 & 16 & 11 & 172 & 5 & 7 & 0.7 & 0.02 & 1 & 1.1 & 0.40 & 72 \\
\hline Fonte de Bañiño & 697 & 684 & 29 & 22 & 11 & 2.0 & 276 & 12 & 8 & & 0.18 & 3 & 1.1 & & 58 \\
\hline Burgo de Arriba & 617 & 516 & 3 & 23 & 12.55 & & 207 & 5 & 10 & & 0.039 & 1 & 19.8 & & 85.6 \\
\hline \multicolumn{16}{|l|}{ Sodium chlorinated waters } \\
\hline Caldelas de Tui & 713 & 98 & 37 & 281 & 14 & 26 & 226 & 11 & 10 & 0.5 & 0.02 & 1 & 1.1 & 0.00 & 99 \\
\hline Acuña & 728 & 152 & 19 & 269 & 21 & 3 & 243 & 5 & 7 & 0.7 & 0.02 & 1 & 1.1 & 0.10 & 53 \\
\hline Dávila & 720 & 164 & 17 & 268 & 17 & 5 & 247 & 4 & 7 & 0.7 & 0.02 & 1 & 1.1 & 0.02 & 58 \\
\hline Xardin das Burgas & 617 & 9 & 2.882 & 24.11 & 10.26 & & 203.69 & 12.02 & 8.68 & 1.29 & 0.14 & 0.71 & & & 16.2 \\
\hline
\end{tabular}

Table 5. Chemical compositions of the mineral-medicinal waters of medium mineralization (mg/L) 


\begin{tabular}{|c|c|c|c|c|c|c|c|c|c|c|c|c|c|c|c|}
\hline \multirow{2}{*}{$\begin{array}{l}\text { Spas/springs } \\
\text { Weak Mineralization } \\
(250-500 \mathrm{mg} / \mathrm{L})\end{array}$} & \multirow{2}{*}{$\begin{array}{l}\text { Dry } \\
\text { residue }\end{array}$} & \multicolumn{5}{|l|}{ Anions } & \multicolumn{6}{|c|}{ Cations } & \multicolumn{2}{|c|}{ Gas phase } & \multirow{2}{*}{$\begin{array}{l}\text { Silica } \\
\mathrm{SiO}_{2}\end{array}$} \\
\hline & & $\mathrm{HCO}_{3}$ & $\mathrm{SO}_{4}$ & Cl & $\mathbf{F}$ & HS & $\mathrm{Na}$ & Ca & $\mathbf{K}$ & $\mathbf{L i}$ & $\mathbf{F e}_{\text {total }}$ & Mg & $\mathrm{CO}_{2}$ & $\mathbf{H}_{2} \mathrm{~S}$ & \\
\hline \multicolumn{16}{|l|}{ Sodium bicarbonate waters } \\
\hline Cortegada & 351.6 & 220 & 10 & 47 & 34.4 & 7.63 & 120 & 1 & 3 & 2.10 & 0.036 & 1 & 1.1 & & 66 \\
\hline Baños de Brea & 412 & 207 & 31 & 64 & 23 & 28 & 112 & 5 & 7 & 1.90 & 0.036 & 3 & 4.4 & 12 & 106 \\
\hline Lugo & 421 & 186 & 78 & 47 & 18 & 17 & 135 & 5 & 6 & 0.60 & 0.020 & 1 & 1.1 & 3.20 & 75 \\
\hline Arnoia & 273 & 124 & 35 & 45 & 24 & 28 & 3.958 & 0.25 & 0.054 & 0.54 & 0.020 & 0.082 & 0 & 0.10 & 65 \\
\hline Augas Santas-Pantón & 461.4 & 188 & 80 & 39 & 28.8 & 20.73 & 129 & 7 & 5 & 3 & 0.0001 & 3 & 1.1 & & 41.9 \\
\hline $\begin{array}{l}\text { Baños Viejos de } \\
\text { Carballo }\end{array}$ & 450 & 117 & 75 & 57 & 25 & 36 & 144 & 1 & 4 & 1.60 & 0.020 & 1 & 1.1 & 0 & 67 \\
\hline O Tremo & 251 & 138 & 36 & 36 & 11 & 16 & 96 & 2 & 1 & & 0.027 & 1 & 1.1 & 3.16 & 29 \\
\hline Guitiriz & 262 & 74 & 15.3 & 29.3 & 14.5 & 66 & 83 & 2.3 & 0.83 & 0.62 & 0.330 & 0.094 & & & 20 \\
\hline $\begin{array}{l}\text { Termas da } \\
\text { Chavasqueira }\end{array}$ & 403 & 322 & 9 & 19 & 17.1 & 2.59 & 138 & 2 & 5 & & 0.030 & 1 & 1.1 & & 72.6 \\
\hline \multicolumn{16}{|l|}{ Sodium chlorinated waters } \\
\hline Termas de Cuntis & 310.4 & 91 & 45 & 38 & 20.3 & 8.45 & 93 & 5 & 2 & 1 & 0.020 & 4 & 1.1 & 0 & 91.4 \\
\hline
\end{tabular}

Table 6. Chemical compositions of the mineral-medicinal waters of weak mineralization (mg/L)

\begin{tabular}{|c|c|c|c|c|c|c|c|c|c|c|c|c|c|c|c|}
\hline \multirow{2}{*}{$\begin{array}{l}\text { Spas/springs } \\
\text { Very weak mineralization } \\
(100-250 \mathrm{mg} / \mathrm{L})\end{array}$} & \multirow{2}{*}{$\begin{array}{l}\text { Dry } \\
\text { residue }\end{array}$} & \multicolumn{5}{|l|}{ Anions } & \multicolumn{6}{|c|}{ Cations } & \multicolumn{2}{|c|}{ Gas phase } & \multirow{2}{*}{$\begin{array}{l}\text { Silica } \\
\mathrm{SiO}_{2}\end{array}$} \\
\hline & & $\mathrm{HCO}_{3}$ & $\mathrm{SO}_{4}$ & $\mathbf{C l}$ & $\mathbf{F}$ & HS & $\mathrm{Na}$ & Ca & $\mathbf{K}$ & $\mathbf{L i}$ & $\mathbf{F e}_{\text {total }}$ & $\mathrm{Mg}$ & $\mathrm{CO}_{2}$ & $\mathbf{H}_{2} \mathrm{~S}$ & \\
\hline \multicolumn{16}{|l|}{ Sodium bicarbonate waters } \\
\hline Ponte Caldelas & 247.8 & 181 & 12 & 25 & 15.6 & - & 91.9 & 1 & 1.49 & - & 0.040 & 1 & - & - & 42.6 \\
\hline Baños de Berán & 240 & 74 & 14 & 16 & 9.8 & 2.3 & 49.3 & 6.7 & 1.3 & 0.9 & 0.02 & 0.46 & - & 0.5 & 43 \\
\hline O Carballiño & 198 & 59 & 24 & 32 & 10 & 20 & 56 & 1 & 1 & - & - & 1 & - & - & 56 \\
\hline Castro Caldelas & 186.9 & 118.3 & 16.8 & 3.5 & 0.2 & - & 35.1 & 3.1 & 0.1 & 0.08 & 0.002 & 1.7 & - & 5.7 & 1.6 \\
\hline
\end{tabular}

Table 7. Chemical compositions of the mineral-medicinal waters of very weak mineralization (mg/L)

\section{Therapeutic indications}

From the standpoint of medical hydrology, the effects of the mineral-medicinal waters according to their predominant composition are shown in Table 8 (Maraver 2002). Likewise, the distribution of the therapeutic indications of various mineral-medicinal waters is collected in Table 9 , taking into account the spatial distribution of the mineral-medicinal waters 


\section{Mineral water actions due to mineral compositions}

Chlorinated

Sulphated

Bicarbonated

Carbogaseous

Sulphur

Ferruginous

Radioactive

With mineralization lower than $500 \mathrm{mg} / \mathrm{L}$
Stimulate organic and metabolic functions

Enhance cell tropism; scarring processes and tissue repair Improve blood and lymphatic circulation

Purgatives

Choleretic

Cholagogues and stimulants of intestinal peristalsis

Antacids

Increase pancreatic activity

To favour the saponifier power of fat by bile

Hepatoprotective

Favour glycogenesis

Favour the mobilization and elimination of uric acid in urine

Orally: (more than $1000 \mathrm{mg} / \mathrm{L}$ )

Aid digestion and mask flavours

Stimulate secretions and gastric motility

Facilitate intestinal function

Topically (more than $400 \mathrm{mg} / \mathrm{L}$ )

Peripheral vasodilatation

Decrease the thermal threshold

Activate metabolic oxide-reducing processes

Anti-toxic effects, antiallergics and trophism improvers

Regulatory actions of respiratory secretions

Immunological effects on the skin

Activate haematopoiese and cell oxidative functions Improve tissue trophism

Sedative and analgesic

Antispasmodic and decontracting

Regulators of the vegetative nervous system

Diuretic

Washing and dragging of all kinds of stone

Table 8. Therapeutic actions associated with medicinal mineral waters 
Therapeutic indications of the main Galician waters

A Toxa

Rheumatology

Arteixo

Baños de Molgas

Xardín das Burgas

Laias

Baños Viejos de Carballo

Lugo

Cortegada

Arnoia

Lobios

Baños de Loureda

Termas de Cuntis

Caldas de Partovia

Dávila

Respiratory

Acuña

Caldelas de Tui

O Carballiño

Hepatobiliary

Guitiriz

Pardiñas

Agua de Fonte Nova-main spring

Gastroenterology

Agua cabreiroá with Gas 2

Mondariz (Gándara)

Sousas-Sprinq 1

O Incio

Aguas Santas-Pantón

Dermatology

Baños de Brea

Ponte Caldelas

Charca do Allegal

O Tremo

Río Pambre

Baños de Berán

Table 9. Therapeutic indications of Galician waters 


\section{Conclusions}

This paper presents a study of the chemical characteristics of the mineral and thermal waters of Galicia. The chemical qualities of the different springs are related to the geological mineralizations of the medium, the ascending flow velocity, the depth of the thermal focus, the water paths and the proximity to the coast. Thus, in general, the springs closest to the coastal zones are characterized by being sodium chlorinated, while the inland ones are sodium/potassium bicarbonated.

The more mineralized waters are those that come from greater depths with longer paths. These waters can have high temperatures when upwelling. These waters circulate slowly and follow a regional flow path. In addition, there are some ferruginous springs coming from areas with reduced sulphur waters, where sulphur has not oxidized to sulphate.

\section{Acknowledgements}

We want to give special thanks to Helder Chaminé for the invitation to write this article and to publish in Sustainable Water Resources Management.

\section{References}

1. Baeza J, López Geta J, Ramírez A (eds.) (2001) Las Aguas Minerales en España. Instituto eológico y Minero de España, Spain, p 454

2. .Carvalho JM (1996) Mineral water exploration and exploitation at the Portuguese Hercynian Massif. Envir Geol 27:252-258.

3. Chamorro CR, García-Cuesta JL, Mondéjara ME, Linares MM (2014) An estimation of the enhanced geothermal systems potential for the Iberian Peninsula. Renew Energy 66:114

4. Chebotarev II (1955) Metamorphism of natural waters in the crust of weathering (1). Geochim Cosmochim Acta 8:22-48

5. Comstock GW (1979) Water hardness and cardiovascular diseases. Am J Epidemiol 110(4):375-400

6. Corral MM, Ontiveros C and López-Geta JA (2012) Recent contributions of the geological survey of Spain (IGME) in mineral water. In: Medical hydrology and Balneology: environmental aspects. Balnea 6, p 226

7. Coudrain-Ribstein A, Gouze P, de Marsily G (1998) Temperaturacarbon dioxide partial pressure trends in confined aquifers. Chem Geol 145:73-89

8. Craig H (1963) The isotopic geochemistry of water and carbon in geothermal areas. In: Tongiorgi E (ed) Nuclear geology in geothermal areas. Proceeding International Symposium, Spoleto, Italy, Consiglio Nazionale delle Ricerche, Laboratorio di Geologic Nucleare, Pisa, Italy, pp 15-73

9. D'Amore F (1991) Application of geochemistry in geothermal reservoir development; United Nations Institute for Training and Research; UNITAR Man/10, p 408

10. Davis SN, De Wiest RJM (1966) Hydrogeology. Wiley, NY, pp 96-128

11. Delgado J, Juncosa R, Meijide R, Vázquez A, Barrientos V (2007) Características termohidrogeoquímicas de las aguas subterráneas en Galicia. In: HI Chaminé, JM Carvalho (eds.) O valor acrescentado das Ciências da Terra no termalismo e no engarrafamento da água, Artigos seleccionados do II Fórum Ibérico de Águas Engarrafadas e Termalismo. Edição do Departamento de Engenharia Geotécnica/Laboratório de Cartografia e Geologia Aplicada, Instituto Superior de Engenharia do Porto, Porto, p. 281-299.

12. Delgado J, Juncosa R, Hernández H, Falcón I, Vázquez A (2011) Comparative Hydrochemistry of five nested catchments located in the upper part of the Barces river watershed (A coruña, NW Spain). Appl Geochem 26:179-182. 
13. Delgado J, Juncosa R, Falcón I, Canal J (2013) Four years of continuous monitoring of the Meirama end-pit lake and its impacts in the definition of future uses. Environ Sci Pollut Res 20(11):7520-7533.

14. D1074/2002. Real Decreto 1074/2002, de 18 de octubre, por el que se regula el proceso de elaboración, circulación y comercio de aguas de bebida envasadas.

15. D1798 2010 Real Decreto 1798/2010, de 30 de diciembre, por el que se regula la explotación y comercialización de aguas minerales naturales y aguas de manantial envasadas para consumo humano.

16. Fournier RO and Potter RW II (1982) An equation correlating the solubility of quartz in waters from 25 to $900{ }^{\circ} \mathrm{C}$ at pressures up to 10.000 bars; Geochim Cosmochim Acta 46, 1.969-1.974

17. Fournier RO, Rowe JJ (1966) Estimation of underground temperatures from the silica content of water from hot springs and wetsteam wells. Am J Sci 264:685-697

18. Gibbons W, Moreno T (eds.) (2002) The Geology of Spain. Geological Society of London, London, p 632

19. Giggenbach WF (1988) Geothermal solute equilibria. Derivation of Na-K-Mg-Ca geoindicators. Geochim Cosmochim Acta 52:2749-2765

20. Giggenbach WF (1992) Isotopic shifts in waters from geothermal and volcanic systems along convergent plate boundaries and their origin. Earth Planet Sci Lett 113:495-510

21. Giggenbach WF (1997) The origin and evolution of fluids in magmatic-hydrothermal systems. In: Barnes HL (ed.) Geochemistry of Hydrothermal Ore Depoits, 3rd edn. Wiley, Hoboken, pp737-796

22. Giggenbach WF, Goguel RL (1989) Collection and analysis of geothermal and volcanic water and gas discharges; Report No CD 2401. Department of Scientific and Industrial Research. Chemistry Division, Petone

23. Harper KJ (2008) Potassium, magnesium and calcium: their role in both the cause and treatment of hypertension. J Clin Hypertens (Greenwich) 10(7 suppl 2):3-11

24. Haselton HT, Sharp WE, Newton RC (1978) CO2 fugacity at high temperaturas and pressures from experimental decarbonation reactions. Geophys Res Lett 5(9):753-756

25. Hem JD (1991) Study and Interpretation of the chemical characteristics of natural waters. 3rd edn. US Geological Survey Water-Supply Paper 2254, p 363.

26. Henley RW, Truesdell AH, Barton PB Jr (1984) Fluid-mineral equilibria in hydrothermal systems; society of economic geologists. Rev Econ Geol 1:267

27. Hernández H, Padilla F, Juncosa R, Vellando P, Fernández A (2012) A numerical solution to integrated water flows: application to the flooding of an open pit mine at the Barcés river catchment—La Coruña, Spain. J Hydrol 422-473:328-339.

28. Hounslow AW (1995) Water quality data: analysis and interpretation. Lewis Publishers, Boca Raton, p 397

29. Juncosa R, Meijide R, Delgado J (2011) Fontes minerais da Galicia: Características hidroxeolóxicas, físico-químicas e indicaÇoes terapéuticas. In: Alberto Lima (ed.) Termalia'11-Encontro Internacional sobre Âguas termais. Universidade do Minho, Portugal, pp 51-73

30. Juncosa R, Delgado J, Meijide R, Álvarez-Campana J (ed.) (2012) Hidrogeología de Galicia y tipos de aguas subterráneas. In: Rio Mandeo, cuenca fluvial y desarrollo sostenible. Diputación de A Coruña, Coruña, pp 177-203

31. Juncosa R, Delgado J, Menéndez JA, Valle R (2015) Análisis hidrogeológico de la escombrera exterior de la antigua mina de As Pontes. Ing del Agua 19(2):75-87

32. Langmuir DM (ed.) (1996) Aqueous environmental geochemistry. Prentice Hall, NJ

33. Luft FC, Zemel MB, Sowers JA, Fineberg NS, Weinberger MH (1990) Sodium bicarbonate and sodium chloride: effects on blood pressure and electrolyte homeostasis in normal and hypertensive man. J Hypertens 8:663-670

34. Mahon WAJ (1966) Silica in hot water discharged from drillholes at Wairakei, New Zealand. NZ J Sci 9:135-144

35. Maraver F (2002) Vademecun de aguas mineromedicinales españolas. Instituto de Salud Carlos III: Universidad Complutense de Madrid. p 310

36. Marques JM, Carreira PM, Aires-Barros L, Graça R (2000) Nature and role of CO2 in some hot and cold $\mathrm{HCO} 3 / \mathrm{Na} / \mathrm{CO} 2$-rich Portuguese mineral waters: a review and reinterpretation. Environ Geol 40:53-63

37. Marques JM, Monteiro Santos FA, Graça R, Castro R, Aires-Barros L and Mendes Victor LA (2001) A geochemical and geophysical approach to derive a conceptual circulation model of CO2-rich mineral waters: a case study of Vilarelho da Raia, northern Portugal. Hydrogeol J 9:584-596 
38. Marques JM, Espinha J, Carreira PM, Graça R, Aires-Barros L, Carvalho JM, Chaminé HI, Borges FS (2003) Geothermal fluids circulation at Caldas do Moledo area, Northern Portugal: geochemical and isotopic signatures. Geofluids 3:189-201

39. Marques JM, Carreira PM, Espinha Marques J, Chaminé HI, Fonseca PE, Monteiro Santos FA, Eggenkamp HGM, Teixeira J (2010) The role of geosciences in the assessment of low-temperature geothermal resources (N Portugal): a review. Geosc J 14(4):423-442

40. Marques JM, Carreira PM, Goff F, Eggenkamp HGM, Antunes da Silva M (2012) Input of $87 \mathrm{Sr} / 86 \mathrm{Sr}$ ratios and $\mathrm{Sr}$ geochemical signatures to update knowledge on thermal and mineral waters flow paths in fractured rocks (N-Portugal). Appl Geochem 27:1471-1481

41. Martínez Catalán JR, Aller J, Alonso JL, Bastida F (2008) The Iberian Variscan Orogen. In García-Cortés A, Suárez-Valgrande JP, Salvador-González CI (eds.), Spanish Geological Frameworks and Geosites: an approach to Spanish geological heritage of international relevance. Instituto Geológico y Minero de España, Madrid, pp 15-30

42. Martínez-Pledel B, Ontiveros B and Corral M (2012) Galicia. Mineral and thermal waters. In: medical hydrology and balneology: environmental aspects. Balnea 6. 4, p 457

43. Matz H, Orion E, Wolf R (2003) Balneotherapy in dermatology. Dermatol ther 16(2):132-140

44. Meyniel, G. (1975) Traité de médicine nucléaire. Explorations fonctionnelles. Vol 2. Flammarion Éditeurs, pp. 260-263

45. Michard G, Beucaire C (1993) Les eaux thermales des granites de Galice (Espagne): des eaux carbogazeuses aux eaux alcalines. Chem Geol 110:345-360

46. Morris RW, Walker M, Lennon LT, Shaper AG, Whincup PH (2008) Hard drinking water does not protect against cardiovascular disease: new evidence from the British Regional Heart Study. Eur J Cardiovasc Prev Rehabil 15(2):185-189

47. Rey D, Rubio B, Bernabeu AM, Vilas F (2004) Formation, exposure and evolution of a high-latitude beachrock in the intertidal zone of the Corrubedo complex (Ria de Arousa, Galicia, NW Spain). Sediment Geol 169:93-105

48. Ribeiro A, Munhá J, Dias R, Mateus A, Pereira E, Ribeiro L, Fonseca PE, Araújo A, Oliveira JT, Romão J, Chaminé HI, Coke C, Pedro J (2007) Geodynamic evolution of the SW Europe Variscides. Tectonics, 26:TC6009

49. SITGA (http://sitga.xunta.es/)

50. Souto MG (1990) Estudio químico-analítico de las aguas minero-termales de la provincia de Orense. Tesis Doctoral. Universidad de Santiago de Compostela, p 398

51. Stumm W, Morgan JJ (1995) Aquatic Chemistry, 3rd edn, Wiley, NY, p 1024

52. Valitutti S, Castellino F, Musiani P (1990) Effect of sulfurous (thermal) water on $\mathrm{T}$ lymphocyte proliferative response. Ann Allergy 65(6):463-468

53. Vera JA (ed.) (2004) Geología de España; Sociedad Geológica de España. Instituto Geológico y Minero de España, p 884

54. Vidal Romaní JR, Yepes J (2001) Las terrazas del río Miño en el tramo Chantada-As Neves (límite de Galicia-Portugal). Acta Geol Hisp 36:149-164

55. Winter TC, Harvey JW, Lehn O, Alley WM (1998) Ground Water and Surface Water. A Single Resource; U.S. Geological Survey Circular 1.13; p87.

56. Young ED (1995) Fluid flow in metamorphic environments. In: U.S. National Report to International Union of Geodesy and Geophysics 1991-1994; reviews in Geophysics 33 Suppl. 